\title{
ASPECTS OF THE EVOLUTION OF AN IMPORTANT GEO-ECOSYSTEM IN THE LESSINIAN MOUNTAIN (VENETIAN PREALPS, ITALY)
}

\section{POGLEDI NA RAZVOJ POMEMBNEGA GEO-EKOSISTEMA V GORAH LESSINI (BENEŠKE PREDALPE, ITALIJA)}

\author{
Leonardo LATELLA ${ }^{1} \&$ Ugo SAURO $^{2}$
}

\begin{abstract}
UDC 551.442:574.4 (234.323.4)

Leonardo Latella \& Ugo Sauro: Aspects of the evolution of an important geo-ecosystem in the Lessinian Mountain (Venetian Prealps, Italy)

The Grotta dell'Arena (476 V/VR), located in the Lessinian Mountain, at the elevation of $1512 \mathrm{~m}$ a.s.l., is a very important underground karst system. Although it is only $74 \mathrm{~m}$ long, several of the geological, geomorphological and environmental features of the High Lessinian underground karst are present in this cave. The Grotta dell'Arena shares some common geological and faunistic characters with other important and well known karst systems. This cave has also one of the highest number of troglobitic species in all Venetian Prealps and some of them possibly originated in the pre-Quaternary. From the geological point of view the cave is the expression of a contact karst, where different limestone types come in contact both stratigraphically and along tectonic structures. The Grotta dell'Arena is located at the stratigraphic contact between the "Calcari del Gruppo di San Vigilio" and the "Rosso Ammonitico" and it is very close to a fault plane putting in vertical contact the two above formations with the "Biancone", a kind of limestone closely stratified and densely fractured, very sensible to frost weathering. It is interesting to note the presence of a good number of species of Tertiary, or more generally pre-Quaternary, originate in the Grotta dell'Arena. This presence is possibly related to the geology of caves. In this paper the different kinds of underground karst systems in the Grottta dell'Arena and Lessinian Mountain, are analyzed and the relation with the cave fauna distribution are taken in consideration.
\end{abstract}

Key words: karst evolution, geomorphology, biospeleology, faunistic invasions, Venetian Prealps, Italy.
Izvleček

UDK 551.442:574.4 (234.323.4) Leonardo Latella \& Ugo Sauro: Pogledi na razvoj pomembnega geo-ekosistema v gorah Lessini (Beneške Predalpe, Italija) Jama Grotta dell'Arena (476 V/VR) v gorah Lessini, $1512 \mathrm{~m}$ n.m., je zelo pomemben podzemeljski kraški sistem. Čeprav je dolga le $74 \mathrm{~m}$, vsebuje geološke, geomorfološke in okoljske elemente, značilne za kraško podzemlje Visokih Lessini. Grotta dell'Arena ima nekaj geoloških in favnističnih značilnosti skupnih z drugimi pomembnimi in znanimi kraškimi sistemi. Jama je med tistimi $\mathrm{z}$ največjim številom troglobiontskih vrst v vseh Beneških Predalpah, od katerih nekatere verjetno izvirajo izpred kvartarja. $Z$ geološkega vidika predstavlja jama kontaktni kras, kjer so vzdolž stratigrafskega in tektonskega stika različni apnenci. Grotta dell'Arena je na stratigrafskem stiku med apnenci "Calcari del Gruppo di San Vigilio" in "Rosso Ammonitico" in je zelo blizu prelomne ploskve, vzdolž katere se vertikalno stikata omenjeni formaciji s formacijo "Biancone", to je vrsta drobnoplastovitega in gosto prepokanega, slabo odpornega apnenca. Zanimiva je prisotnost precejšnjega števila terciarnih oziroma splošneje predkvartarnih vrst. To je verjetno $\mathrm{v}$ zvezi z jamsko geologijo. V prispevku so podrobneje obravnavane različne vrste podzemskih kraških sistemov v sami jami Grottta dell'Arena kot tudi v gorah Lessini in tudi njihovi odnosi z razporeditvijo jamskega živalstva.

Ključne besede: razvoj krasa, geomorfologija, biospeleologija, invazija favne, Beneške Predalpe, Italija.

\footnotetext{
${ }^{1}$ Museo Civico di Storia Naturale di Verona. Lungadige Porta Vittoria, 9, 37129 Verona, Italy. E-mail: leonardo.latella@comune.verona.it

${ }^{2}$ Università degli Studi di Padova, Dipartimento di Geografia. Via del Santo 26, 35123 Padova, Italy. E-mail: ugo.sauro@unipd.it Received/Prejeto: 21.12.2006
} 


\section{INTRODUCTION}

The Grotta dell' Arena is registered with the number 476 in the Cadastre of the Caves of Veneto Region (the cave has been surveyed by A. Pasa in 1942, and GAS USV in 1972); the karst area is ML03 (Monti Lessini 03). The cave is $74 \mathrm{~m}$ long with a difference in elevation of - $22 \mathrm{~m}$. It is located in the Lessinian Mountain district of Bosco Chiesanuova, in Malga Bagorno area. G.C: $11^{\circ} 06^{\prime} 02^{\prime \prime} \mathrm{E}$ $45^{\circ} 39^{\prime} 56^{\prime \prime} \mathrm{N}$, elevation $1512 \mathrm{~m}$ a.s.l.

The Grotta dell'Arena is a significant kind of underground karst system in Lessinian Mountain in fact:

- it is a type of speleogenetic style in the morphodynamic context of the High Lessinians,

- several of the geological, geomorphological and environmental features of the High Lessinian underground karst are present in this cave and played a significant role in karst evolution,

- some of the best known karst systems in the Lessinian Mountain (Mietto \& Sauro, 2000; Rossi \& Sauro,
1977), such as the Abisso della Preta, the Covolo di Camposilvano, the Abisso del Giacinto, the Abisso dei Lesi, the Ponte di Veja, share some common characters with the Grotta dell'Arena,

- from the biospeleological point of view, this cave has one of the highest number of troglobitic species in all Venetian Prealps,

- several troglobitic species are endemic for the Grotta dell'Arena or the Lessinian Mountains and some of them possibly originated in the pre-Quaternary.

The Grotta dell'Arena is a large chamber, roughly elliptical in plane section, with a main diameter of about $50 \mathrm{~m}$. The roof coincides mostly with bedding planes. The southern part of the floor is characterized by a large, asymmetrical, funnel-shaped depression, a kind of subterranean doline developed in the collapse debris.

The chamber is situated a few meters below the topographical surface; it is connected to the surface through

\begin{tabular}{|c|c|c|c|}
\hline Gastropoda & Opiliones & Diplopoda & Orthoptera \\
\hline Zospeum sp. & Ischyropsalis strandi & Lessinosoma paolettii & Troglophilus sp. \\
\hline Anellida & Copepoda & Collembola & Coleoptera \\
\hline Marionina n.sp. & Speocyclops cfr. infernus & Onychiurus hauseri & Orotrechus vicentinus juccii \\
\hline Araneae & Lessinocamptus caoduroi & Pseudosinella concii & Orotrechus pominii \\
\hline Troglohyphantes sp. & Moraria n. sp. & Sincarida & Italaphaenops dimaioi \\
\hline Pseudoscorpiones & Elaphoidella n. sp. & Bathynella sp. & Lessinodytes pivai \\
\hline Chthonius lessiniensis & Isopoda & Amphipoda & Laemostenus schreibersi \\
\hline Neobisium torrei & Androniscus degener & Niphargus galvagnii similis & Halberrria zorzii \\
\hline Balkanoroncus boldorii & & & \\
\hline
\end{tabular}

Tab. 1: List of the cave-dwelling species in the Grotta dell'Arena.

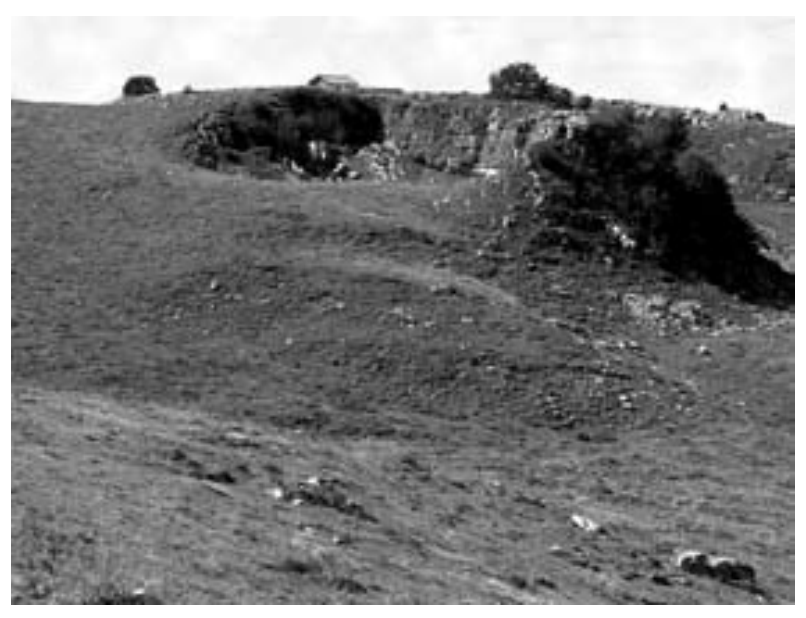

Fig. 1: The collapse depression called Arena.

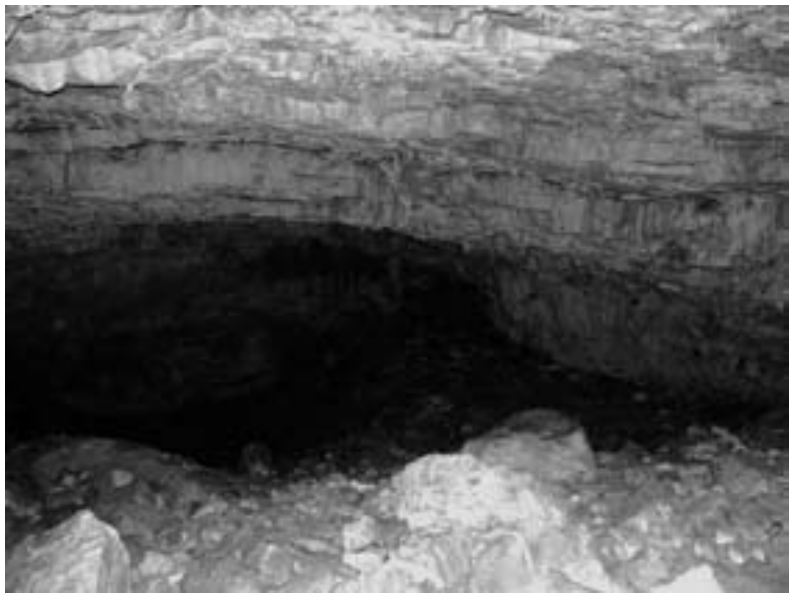

Fig. 2: The large chamber in the Arena cave. In the foreground the debris blocks, in the background the inner "doline". 
some narrow passages which start from an open collapse depression located on a slope, which resembles a Roman theatre (i.e. an "Arena", hence the name of the cave) (Fig.1, Fig. 2). The depression is the result of the collapse of part of the subterranean room.

To understand the significance of this cave it is necessary to:

- delineate the geological, geomorphological, and, in general, environmental characteristics of this cave,
- reconstruct the framework of the spatial and temporal evolution of the High Lessini karst,

- taking into account the climatic and environmental changes of the external environment surrounding the cave that occurred during the Pleistocene.

- analyse the phyilogeographical and taxonomical affinities of the troglobitic elements of its fauna.

\section{THE ENVIRONMENTAL CONTEXT}

The Grotta dell'Arena had been previously defined not as a distinct structure, but as a window on a subterranean space, that allows us to see only some features of a karst system (Castiglioni \& Sauro, 2002). In fact, the subterranean environment is a much more complex system, mostly hidden to the human perception.

From the geological point of view the cave is expression of a contact karst, where different limestone types come in contact both stratigraphically and along tectonic structures (Capello et al. 1954; Pasa, 1954; Sauro, 1973, 1974, 2001). In particular, the limestone formations present here are:

- "Calcari del Gruppo di San Vigilio" of lowermiddle Jurassic, about $60 \mathrm{~m}$ in depth, pure both oolitic and bio-sparitic/-ruditic, or reef limestones, relatively densely fractured,

- "Rosso Ammonitico", a condensed rock unit of middle- upper Jurassic age, about $30 \mathrm{~m}$ in depth, made up by nodular micritic limestone very resistant to erosion, crossed by widely spaced fractures,

- "Biancone", a chalk type unit, from the lower and middle Cretaceous, 100-200 meters in depth, made up by whitish marly limestone closely stratified and densely fractured, very sensible to frost weathering.

The Scaglia Rossa formation of the upper Cretaceous, and the Eocene limestone, which lie above the Biancone in the western and southern part of the plateau are not present in the studied area because they have been completely eroded. Below the "Calcari del Gruppo di San Vigilio" there is the formation "Calcari Grigi di Noriglio", of lower Jurassic, which is about $300 \mathrm{~m}$ in depth and outcrops in the slopes of the main valleys, a kind of fluviokarstic canyons.

The Grotta dell'Arena is located at the stratigraphic contact between the "Calcari del Gruppo di San Vigilio" and the "Rosso Ammonitico" and it is very close to a fault plane putting in vertical contact the two above formations with the Biancone (Fig. 3). The cover rocks of the cave are made mostly by the massive beds of lower Rosso
Ammonitico, whereas the inner cave is mostly developed inside the Calcari del Gruppo di San Vigilio. At the topographical surface, the line of the normal fault runs along

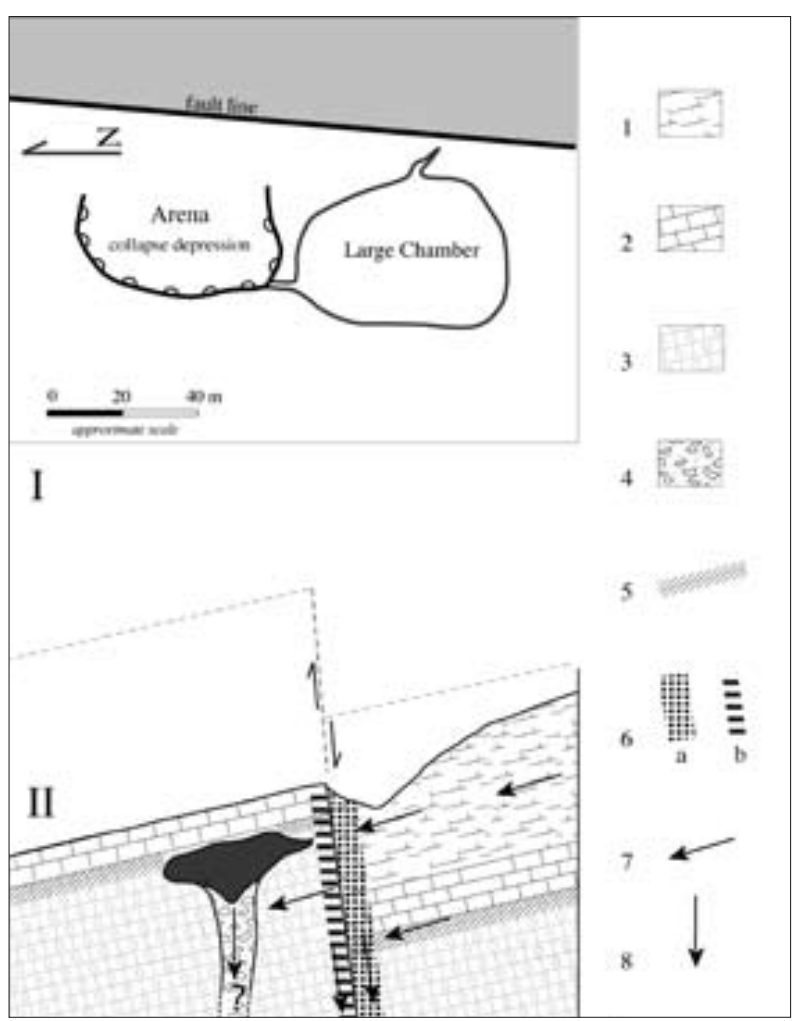

Fig. 3: Sketches of the Arena cave system:

I - Plan of the system; the grey corresponds to the Biancone rock unit.

II - Vertical model of the karst system. Legend: 1) Biancone formation, 2) Rosso Ammonitico, 3) Calcari del Gruppo di San Vigilio and Calcari Grigi, 4) debris pipe in the cave, 5) bedding plane karst zone at the contact Rosso Ammonitico- Calcari del Gruppo di San Vigilio, 6) fault plane karst zone, a) at the Biancone side, b) at the Rosso Ammonitico side, 7) lateral flow inside and from the Biancone aquifer, 8) vertical karst flow. 
a small valley, a few meters to the east of the cave; the displacement of the fault is about $100 \mathrm{~m}$.

From the geomorphological point of view, Biancone is dissected by a network of dry valleys, whereas Rosso Ammonitico generates a rocky landscape with large flat karren separated by corridors, or rock cities of large blocks.

From the hydrological viewpoint, the water circulates diffusely inside the dense network of discontinuities of the Biancone unit; the preferential flows is sub-parallel to the topographical surface and occurs mostly below the dry valley bottoms, but is also influenced by the structural setting; vertical losses occur along the fault and fracture zones. In contrast, water circulation is more concentrated and mostly vertical in the Rosso Ammonitico.

\section{SPATIAL AND TEMPORAL EVOLUTION OF THE KARST SYSTEM}

It is easy to understand that the Grotta dell'Arena results of different spatial and temporal processes which occurred as a consequence of several predisposing factors. In fact, the cave is at the same time, an example of lithological contact karst, of intra-stratal karst, of fault zone karst and of a subterranean hydrological transition from a dispersed and sub-horizontal water flow to a more concentrated and sub-vertical one.

The Grotta dell'Arena system is fed by a lateral water flow coming from the Biancone aquifer and crossing the fault zone, facilitated by the westward dipping of the strata. The speleogenesis of the cave has taken place in the lithological, tectonic and hydrological transition zone.

Each cave we visit represents a moment of a long history, it is like the picture of a movie. Surely the present aspect of this cave and of its collapsed part are the result of relatively recent processes, occurred mostly during the middle and upper Pleistocene. But the karst system of which the cave is expression has surely begun to develop much earlier.

Some caves, located in middle of the Lessinian plateau and in the Berici hills, are the result of the re-activation of old paleokarstic nets developed during the Paleogene (Rossi \& Zorzin, 1989, 1991; Dal Molin et al. 2000); other caves with fillings from the early middle Pleistocene developed mostly during the lower Pleistocene. The Grotta dell'Arena chamber seems to be related with the second group.

The fault to the east side of the cave is a paleotectonic feature of Jurassic age, reactivated during the Cretaceous and later by the Alpine orogenesis during the Paleogene and the Neogene. The area where the cave is located probably emerged from the sea during the Oligocene, as the southern part of the Lessinian plateau. The erosion of the Eocene rock unit occurred during late $\mathrm{Pa}$ leogene and early Neogene. The Scaglia Rossa formation was probably eroded during middle to late Neogene. At the beginning of the Quaternary these two formations disappeared completely in the area (remnants of Scaglia are still present in the western High Lessinian).

A model showing the sequence of landscapes developed in the different rocks by the erosion can be created, based on present-day landscapes of other parts of the Lessini Mountains, where the eroded geological formations are still present. Thus in the southwestern Lessinian Mountain (High Valpolicella) there is an active hydrographic network with gorges entrenched in both Eocene Limestones and in the Scaglia Rossa.

Here, the early morphogenesis, after the emersion and the uplift, has been mostly of the fluvial type, marked by the development of a network of valleys strongly controlled by the tectonic structure. So, a valley developed along the fault line. Following the incision of the Scaglia Rossa, the karst process begun to affect the fault zone. But, it is especially after the erosion of the Scaglia Rossa that the aquifer hosted in the Biancone started to feed a new underground karst system located near to the fault zone of which the Grotta dell'Arena is the present day expression.

From this simple model it is possible to infer that the evolution of the underground karst system started since Neogene, probably since middle- upper- Miocene. The transition from the fluvial environment to the karst environment has been accompanied by the development of a fluviokarstic milieu in the Biancone. In this milieu, which is still present, there is not surface runoff except during exceptional events, but there is a diffuse circulation inside the rock, for some aspects similar to that occurring below the river beds, inside the alluvial deposits (Fig. 4). 


\begin{tabular}{|c|c|c|c|c|c|}
\hline \multicolumn{3}{|c|}{ STRATIGRAPHICAL SEQUENCE } & SURFACE PROCESSES & $\begin{array}{l}\text { UNDERGROUND } \\
\text { PROCESSES }\end{array}$ & $\begin{array}{l}\text { MAIN TYPES OF } \\
\text { SURFACE FORMS }\end{array}$ \\
\hline EOCENE LIMESTONE & \multirow{6}{*}{\multicolumn{2}{|c|}{ 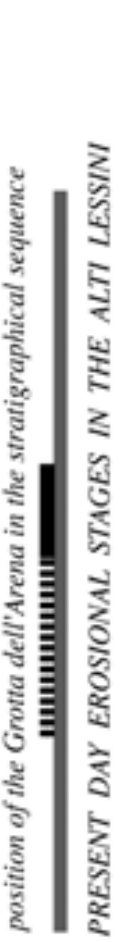 }} & $\begin{array}{l}\text { fluvial erosion } \\
\text { and downcutting }\end{array}$ & $\begin{array}{l}\text { development of a thin } \\
\text { and scattered }\end{array}$ & gorges and valleys \\
\hline SCAGLIA ROSSA & & & $\begin{array}{l}\text { karst denudation } \\
\text { and others } \\
\text { mass movements and } \\
\text { weathering processes }\end{array}$ & $\begin{array}{l}\text { underground karst } \\
\text { development of a } \\
\text { vertical karst, mostly } \\
\text { along the fractures }\end{array}$ & \\
\hline BIANCONE & & & $\begin{array}{l}\text { fluviokarstic } \\
\text { erosion }\end{array}$ & $\begin{array}{l}\text { diffuse karst with } \\
\text { hanging aquifers }\end{array}$ & dry valleys \\
\hline ROSSO AMMONITICO & & & mainly karstic & focalization of & karren and rock cities \\
\hline $\begin{array}{l}\text { CALCARI DEL GRUPPO } \\
\text { DI SAN VIGILIO }\end{array}$ & & & & $\begin{array}{l}\text { the speleogenesis } \\
\text { with development } \\
\text { of large cavities }\end{array}$ & dolines and collapse dolines \\
\hline $\begin{array}{c}\text { AND } \\
\text { CALCARI GRIGI }\end{array}$ & & & & $\begin{array}{l}\text { development of deep } \\
\text { networks feeding the } \\
\text { base level aquifer }\end{array}$ & $\begin{array}{l}\text { inherited network } \\
\text { of dry valleys }\end{array}$ \\
\hline
\end{tabular}

Fig. 4: Sketch of the morphological evolution of the alti Lessini according with the erosional stages reached by the relief (progressive erosion of the rock units).

\section{THE CLIMATE AND ENVIRONMENTAL CHANGES DURING THE PLEISTOCENE}

The Lessinian Mountain plateau was affected by the climatic and environmental changes of the Pleistocene. In the cave area there is no evidence of past development of local glaciers (the nearest local glacier was more than 1 $\mathrm{km}$ to the northwest). However, traces of strong periglacial processes, such as remnants of small rock glaciers, nivation niches, etc. are present (Sauro, 2002). During the last Würm sporadic permafrost was present in the area. The material resulting from the collapse of the Are- na depression has been affected by cryoclastic processes, as shown by a large solifluction lobe located to the north side of the same hollow.

The climate and enviromental change occurred in the Pleistocene, affected the colonization of the subterranean environment by some actual troglobitic species and shaped the distribution of the species that colonized this environments before the Pleistocene.

\section{THE CAVE FAUNA AT PRESENT}

The cave fauna of the Grotta dell'Arena is characterized by the presence of high number of troglobitic and endemic species (Caoduro \& Ruffo, 1998). Colonization of the cave by the troglobitic elements occurred in differ- ent times. Ancient elements of this fauna colonized the subterranean environments before the Pleistocene, and other species invaded the cave in different periods along the Quaternary. 
Today, this cave has a high number of cave-adapted animals. Of the 43 taxa known for the cave, 24 could be considered eucavernicolous species (sensu Ruffo, 1955: eutroglophiles+troglobites). The specialization index (eutroglobites/ eucavernicolous), has a value of 0.91, this means that $91 \%$ of the cave species in the Grotta dell'Arena are troglobionts.

\section{FINAL REMARKS}

The subterranean karst of the alti Lessini is much more spatially developed than what is perceived by a speleologist. It consists not only in large pits and chambers but in a network of smaller cavities and fissures. In the two horizontal dimensions it is a kind of net, even if anisotropic, better developed along the fault zones and some bedding planes. In the vertical dimension the anisotropy is even greater, and the thickness overpasses one thousand of meters.

In the time dimension, this karst network has evolved progressively, even with different speeds influenced by the changes of the morphostructural setting and of the external environment. The karst morphogenesis occurred as result of the co-occurrence of various favourable conditions.

The hydro-geological condition of the alluvial deposits of the water courses of the early erosional stage, during middle Neogene, are no present here nowadays, but there are situation for some aspects similar both below the valley bottoms of the Biancone and in the diffuse net of karst fissures developed inside this rock unit. This diffuse aquifer is in contact with the more typical karst aquifer of the limestone of the Jurassic rock units.

Likewise, some of the larger karst pockets developed in the Eocene limestone, may have had some connections with the karst cavities in the Scaglia, and, along the main fault structures or volcanic structures, also with the karst voids in the Jurassic rock units.
Here, sudden and sharp changes of conditions of the underground environments have not occurred during the late Neogene and the Pleistocene. Even the abrupt climatic changes of the Pleistocene have had a limited influence on the underground environments, according with the large thickness reached by it before the end of Neogene.

It is interesting to note the presence of a good number of species of Terziary, or generally pre-Quaternary, origin in the Grotta dell'Arena. The most important relict species are: Balkanoroncus boldorii (Beier, 1931), Lessinocamptus caoduroi Stoch, 1997, Italaphaenops dimaioi Ghidini, 1964 and Lessinodytes pivai Vigna Taglianti e Sciaky, 1988 (Casale \& Vigna Taglianti, 1975; Vigna Taglianti \& Sciaky, 1988; Gardini, 1991; Galassi pers. com.).

The presence and distribution of these species inside the caves of Lessinia (particularly the terrestrial species) has been usually related to certain environmental characteristic like temperature, humidity, air circulation etc. However, on the basis of the actual knowledge (Latella \& Verdari, 2006), it appears that all these species are present in caves with a large range of temperatures, altitude and morphology. All these caves are developed inside, or in contact with, the Biancone or Scaglia (Cretaceous limestone) formations. It is likely that the geomorphology of the cave plays an important role not only in shaping the historical distribution, but also the actual presence, of cave animals in Lessinian area.

\section{ACKNOWLEDGMENTS}

We are grateful to Sandro Ruffo for the helpful discussions and for the reading of the manuscript. We also thanks Augusto Vigna Taglianti for the informations re- garding Trechinae, Diana Galassi for the informations on Copepoda and Beatrice Sambugar for the Anellida. Thanks to Cristina Bruno for the linguistic review. 


\section{REFERENCES}

Caoduro, G. \& Ruffo, S., 1998: La Grotta dell'Arena, un biotopo di eccezionale interesse negli alti Lessini. La Lessinia ieri oggi domani: quaderno culturale 1998, 39-44.

Casale, A. \& Vigna TAglianti, A., 1976: Note su Italaphaenops dimaioi Ghidini (Coleoptera, Carabide). Bollettino del Museo Civico di Storia Naturale di Verona, 2 (1975): 293-314.

Capello, C.F., Nangeroni, G., Pasa, A., Lippi Boncampi, C., Antonelli, C. \& Malesani, E., 1954: Les phénoménes karstiques et l'hydrologie souterraine dans certaines régions de l'ltalie. Assoc. Intern. Hydrol., vol. 37, n. 2, pp. 408-437, figg. 5, Paris.

Castiglioni, B. \& Sauro, U., 2002: Paesaggi e geosistemi carsici: proposte metodologiche per una didattica dell'ambiente. In: Varotto M. \& Zunica M. (a cura di) - Scritti in ricordo di Giovanna Brunetta. Dipartimento di Geografia "G. Morandini”, Università di Padova, 51-67.

Dal Molin, L., Mietto, P. \& Sauro, U., 2000: Considerazioni sul paleocarsismo terziario dei Monti Berici: la Grotta della Guerra a Lumignano (Longare - Vicenza). Natura Vicentina 4, 33-48 (ISSN 1591-3791).

Gardini, G., 1991: Pseudoscorpioni cavernicoli del Veneto (Arachnida). (Pseudoscorpioni d'Italia XIX). Bollettino del Museo Civico di Storia Naturale di Verona, 15 (1988): 167-214.

Latella, L. \& Verdari, N., 2006: Biodiversity and biogeography of Italian Alps and Prealps cave fauna. Abstracts 18th International Symposium of Biospeleology, Cluj-Napoca, Romania, 10-5 July 2006: 9-10.

Mietto, P. \& Sauro, U., (eds), 2000: Le Grotte del Veneto: paesaggi carsici e grotte del Veneto. Second edition, Regione del Veneto-La Grafica Editrice, 480 pp.
Pasa, A., 1954: Carsismo ed idrografia carsica del Gruppo del Monte Baldo e dei Lessini Veronesi. C.N.R., Centro Studi per la Geografia Fisica, Bologna, Ricerche sulla morfologia e idrografia carsica, n. 5, 150 pp.

Rossi, G. \& Sauro, U., 1977: L’Abisso di Lesi: analisi morfologica e ipotesi genetiche. Le Grotte d'Italia, (4) 6 1976): 73-100.

Rossi, G. \& Zorzin, R., 1989: Fenomeni paleocarsici nei Lessinian Mountain Centrali Veronesi. La Lessinia ieri oggi domani: quaderno culturale 1989, 47-54.

Rossi, G. \& Zorzin, R., 1991: Nuovi dati sui fenomeni paleocarsici dei Covoli di Velo (M.ti Lessini Verona). Atti XVI Congr. Naz. di Speleologia, Udine, 169174.

Ruffo, S., 1955: Le attuali conoscenze sulla fauna cavernicola della regione pugliese. Memorie di Biogeografia adriatica, 3: 1-143.

Sauro U., 2002: Quando in Lessinia c'era il grande gelo. Quaderno Culturale - La Lessinia ieri oggi domani - 2002, 85-94.

Sauro, U., 1973: Il Paesaggio degli alti Lessini. Studio geomorfologico. Museo Civ. di St. Nat. di Verona, Mem. f. s., 6, $161 \mathrm{pp}$.

Sauro, U., 1974: Aspetti dell'evoluzione carsica legata a particolari condizioni litologiche e tettoniche negli Alti Lessini. Boll. Soc. Geol. It., 93, 945-969.

Sauro, U., 2001: Aspects of contact karst in the Venetian Fore-Alps. Acta Carsologica, Ljubljana, 30(2), 89102, 2001.

Vigna Taglianti \& Sciaky R., 1988: Il genere Lessinodytes Vigna Taglianti, 1982 (Coleoptera, Carabidae, Trechinae). Fragmenta Entomologica, 20 (2): 159-180. 
